\title{
Persistent right umbilical vein: its incidence and clinical importance
}

\author{
Ebru Çelik Kavak (D), Salih Burçin Kavak (D), Cengiz Şanlı (D), Gülay Bulu (D), Ibrahim Batmaz (iD, \\ Seren Özden (iD), Hasan Burak Keser (i) \\ Department of Obstetrics and Gynecology, Faculty of Medicine, Firat University, Elazı̆̆, Turkey
}

\begin{abstract}
Objective: To investigate the incidence and concomitant findings of persistent right umbilical vein (PRUV).

Methods: The study was conducted by retrospective review of the data of 1856 patients who admitted to the Clinic of Obstetrics and Gynecology of Firat University between December 2018 and December 2019 for the gestational examination between 14 and 28 weeks of gestation. The obstetric characteristics of the patients such as age, number of pregnancy, abortion, parity and body mass index were recorded. The diagnosis of PRUV was established in the conditions where portal vein reaches to stomach abnormally (roughly, course towards stomach instead of parallel course), fetal gall bladder locates in the medial of umbilical vein or umbilical vein connects to right portal vein abnormally instead of left portal vein. In the cases diagnosed with PRUV, the isolated persistent right umbilical vein or its association with other anomalies was recorded. Ultrasonography findings (minor markers) were also recorded in these cases.

Results: During the study period, 1856 pregnant women were evaluated for gestational examination. Five cases were established with the diagnosis of PRUV. Accordingly, PRUV prevalence was $0.27 \%$. The PRUV incidence in the study population was $1 / 370$ in the study population. No chromosomal anomaly was found in PRUV cases, but one case had echogenic intracardiac focus, one case had echogenic intestine, and one case had short nasal bone. When organ systems were evaluated, renal cyst was found in one case. No additional finding was found in one case.

Conclusion: PRUV is the most common form among fetal venous system anomalies. If detected, fetal examination is required in terms of the anomalies that may accompany. Chromosome analysis is not necessary if it is isolated, and it should be evaluated as a variant of normal anatomy.
\end{abstract}

Keywords: Persistent right umbilical vein, ultrasonography, incidence.

\section{Özet: Persiste sağ umbilikal ven: İnsidans ve klinik önemi}

Amaç: Persiste sağ umbilikal ven (PSUV) görülme sıklığı ve eşlik eden bulguların incelenmesi.

Yöntem: Çalışma Aralık 2018 ile Aralık 2019 tarihleri arasında F1rat Üniversitesi Kadın Hastalıkları ve Doğum Polikliniği'ne 14-28. gebelik haftalarında gebelik muayenesi için başvuran 1856 hastanın verilerinin retrospektif incelenmesi ile yapild. Hastaların yaş, gebelik sayısı, abortus, parite ve vücut kitle indeksi gibi obstetrik özellikleri kayıt altına alındı. PSUV tanısı için; portal venin mideye doğru anormal şekilde uzanması (kabaca paralel seyir yerine mideye doğru seyir), fetal safra kesesinin umbilikal venin medialinde yer alması veya umbilikal venin sola değil, anormal olarak sağ portal vene bağlanmasının izlenmesi ile tanı konuldu. PSUV tespit edilen olgularda, persiste sağ umbilikal venin izole veya diğer anomalilerle olan birlikteliği kayıt edildi. Bu olgularda diğer ultrasonografi bulguları (minör belirteçler) da kayıt altına alındı.

Bulgular: Çalışmanın yapıldığı tarihler arasında, gebelik muayenesi için 1856 gebe değerlendirildi. Beş olguda PSUV tanısı konuldu. Buna göre PSUV görülme sıklı̆̆ı \% 0.27 olarak tespit edildi. Çalışma popülasyonda PSUV insidansı 1/370 olarak bulundu. PSUV olgularında kromozom anomalisine rastlanmamış olup, bir olguda intrakardiyak ekojenik odak, bir olguda ekojen barsak, bir olguda kısa nazal kemik izlendi. Organ sistemleri değerlendirildiğinde bir olguda renal kist saptandi. Bir olguda ise herhangi bir ek bulguya rastlanmadi.

Sonuç: PSUV, fetal venöz sistem anomalileri içinde en sık görülen formdur. Tespiti halinde eşlik edebilecek anomaliler açısından dikkatli fetal muayene gerekir. İzole olması halinde kromozom incelemesini gerektirmez; normal anatominin bir varyantı olarak değerlendirilmelidir.

Anahtar sözcükler: Persiste să̆ umbilikal ven, ultrasonografi, insidans.

Correspondence: Salih Burçin Kavak, MD. Department of Obstetrics and Gynecology, Faculty of Medicine, Firat University, Elazı̆̆, Turkey. e-mail: burcinkavak1@gmail.com / Received: January 19, 2020; Accepted: May 19, 2020

Please cite this article as: Çelik Kavak E, Kavak SB, Şanlı C, Bulu G, Batmaz İ, Özden S, Keser HB. Persistent right umbilical vein: its incidence and clinical importance. Perinatal Journal 2020;28(2):68-72. doi:10.2399/prn.20.0282005 


\section{Introduction}

Umbilical cord anomalies may include the conditions such as the presence of an extra vein in the cord, anomalies seen in vein course or dimension or the presence of a persisting vein. With the development of color Doppler and 3D ultrasonographic imaging methods, it has become easy to establish prenatal diagnosis for umbilical cord anomalies.

Persistent right umbilical vein (PRUV) is the condition where left umbilical vein which should develop normally becomes obliterated and right umbilical vein remains open during the embryological development. The recent studies report its incidence between $0.2 \%$ and $0.5 \%{ }^{[1,2]}$ This incidence makes PRUV the most common form among fetal venous system anomalies.

PRUV can be seen in the transverse plain imaging of fetal abdomen in the routine fetal screening. ${ }^{[3,4]}$

PRUV cases are categorized under two groups as intrahepatic variant and the extrahepatic type which bypasses liver completely. ${ }^{[3,5,6]}$ In the intrahepatic variant, the umbilical vein proceeds towards stomach on the right sight of gall bladder and merges with the portal vein. In the extrahepatic variant, it may proceed directly to the right atrium, inferior vena cava or iliac veins. ${ }^{[3,7,8]}$ Intrahepatic variant is the variation which is seen $95 \%$ more frequently, and its prognosis is good. On the other hand, extrahepatic type has a poor prognosis due to the hemodynamic changes. ${ }^{[6,9]}$

In our study, we aimed to evaluate our PRUV cases that we found within one-year period.

\section{Methods}

The study was conducted by retrospective review of the data of 1856 patients who admitted to the Clinic of Obstetrics and Gynecology of Firat University between December 2018 and December 2019 for the gestational examination between 14 and 28 weeks of gestation. The ethical approval required for the study was obtained from the Ethics Committee of Frrat University. The study was conducted in accordance with Helsinki Declaration. The obstetric and demographic characteristics of all patients such as age, number of pregnancy, abortion, parity and body mass index were recorded.

The ultrasonographic examination was performed in accordance with the recommendations provided in the up-to-date guidelines of International Society of Ultrasound in Obstetrics \& Gynecology (ISUOG). For determining the gestational age, the last menstrual period was used in the cases with regular menstruation and fetal crown-rump length at 11-14 weeks of gestation during the first trimester was used in other cases. The fetal biparietal diameter (BPD), head circumference (HC), abdominal circumference (AC) and femur diaphysis length (FDL) were measured for the fetal biometry. Fetal abdominal examination was done as defined in the guidelines. Accordingly, abdominal organ situs was determined. Fetal stomach was defined in the normal position on the left. It was found that the intestines were within the abdomen and the umbilical cord reached to fetus through the intact abdominal wall. It was noted that fetal gall bladder was observed on the right upper quadrant beside the liver as well as the left-sided stomach.

The fetus was evaluated in terms of the findings of the ventral wall defects such as omphalocele or gastroschisis on the location where fetal umbilical cord is connected to the abdomen. Cord veins were viewed by using standard ultrasonography and Doppler ultrasonography as a component of routine anatomic examination. The number of veins in the cord and the intrafetal course of the cord were also recorded. The cases found to have two arteries and one umbilical vein in the cord were evaluated as normal cord structure. Abnormal course and persistence in the umbilical vein was considered as the presence of PRUV. Accordingly, the following criteria were used for the diagnosis of PRUV: the conditions where portal vein reaches to stomach abnormally (course towards stomach instead of parallel course), fetal gall bladder locates in the medial of umbilical vein or umbilical vein connects to right portal vein abnormally instead of left portal vein. In addition, the isolated PRUV or its association with other anomalies was recorded. Chromosomal evaluation was recommended for the cases in which additional anomalies were detected.

The fetuses, in which situs inversus, unclear situs and heterotaxia (left and right isomerism) were found, were excluded from the study.

The statistical analysis of the study was done by using SPSS 21.0 package software (SPSS Inc., Chicago, IL, USA). Definitive statistics were used to analyze the data.

\section{Results}

Between December 2018 and December 2019, 1856 patients admitted to the clinic for gestational examination. The age, week of gestation, number of pregnancy, 
parity, abortion numbers and body mass index values of the patients are shown in Table $\mathbf{1}$.

The diagnosis of persistent right umbilical vein was established in 5 cases during the study period. When all cases were evaluated, the prevalence was found $0.27 \%$ (the incidence of persistent right umbilical vein was found $1 / 370$ in the study population). No major anomaly was found in these cases, but minor ultrasonographic markers were found in four cases. Accordingly, the first case had an advanced maternal age and the echogenic focus was found in the right ventricle. No additional finding was detected in the fetal echocardiography examination. The case did not undergo first trimester screening test and did not accept advanced chromosomal evaluation. The echogenic intestine was found in the second case, and the risk for first trimester combined test was low (1/1500). No additional finding was found in the fetal examination of the third case. A simple $12 \times 12 \mathrm{~mm}$ cyst was found on the upper pole of the fetal left kidney in the fourth case, and it was confirmed that the lesion was within kidney in the fetal magnetic resonance imaging which was performed to differentiate potential suprarenal gland pathology. The fifth case admitted at the 26 weeks of gestation and fetal nasal bone shortness [biparietal dimeter $(83 \mathrm{~mm}) /$ nasal bone $(6.9 \mathrm{~mm})>12$ ] was found in the ultrasonography examination; the result of the first trimester combined screening test was $1 / 1000$ and the case did not accept chromosomal invasive evaluation. The intrafetal course of umbilical vein in this last case is shown in Fig. 1.

All cases were reached after labor and it was learnt that their infants did not have any structural or chromosomal anomalies. The obstetric characteristics and the additional characteristics found during gestational examinations of the cases who were found to have persistent right umbilical vein are shown in Table 2 .
Table 1. The obstetric characteristics of the patients.

\begin{tabular}{lc}
\hline Characteristics & Mean \pm SD \\
\hline Age (year) & $23.4 \pm 1.5$ \\
Week of gestation (week) & $22 \pm 1.4$ \\
Number of gestation (number) & $2.1 \pm 0.5$ \\
Parity (number) & $1.3 \pm 0.8$ \\
Abortion (number) & $0.4 \pm 0,6$ \\
BMI ( $\mathrm{kg} / \mathrm{m}^{2}$ ) & $24.2 \pm 1.1$ \\
\hline Total number of cases & 1856 \\
\hline
\end{tabular}

BMI: body mass index; Mean \pm SD: mean \pm standard deviation.

\section{Discussion}

Under normal circumstances, right umbilical vein regresses on the fourth week of embryonal period and completely disappears on the seventh week. Left umbilical vein remains as the single vein moving from placenta to liver. The ultimate course of left umbilical vein is towards the midline of fetal abdomen as it connects to the distal part of the left portal vein. ${ }^{[4,10]}$ The left umbilical vein disappears when the right umbilical vein per-

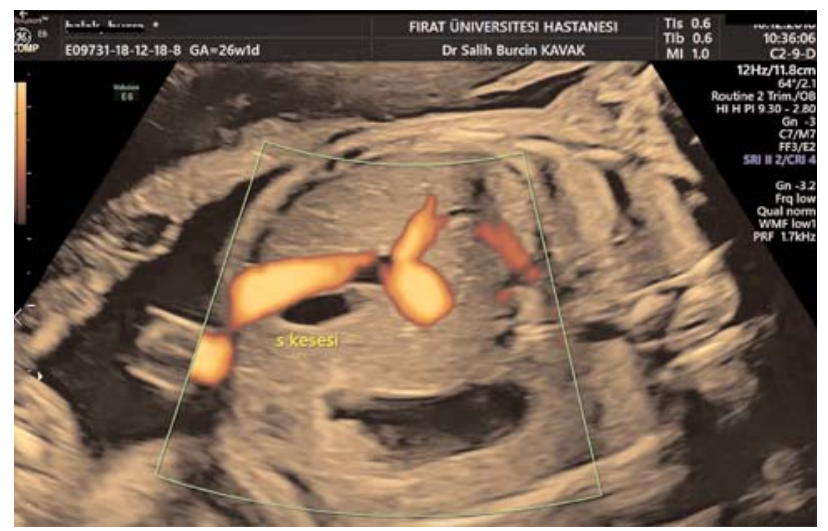

Fig. 1. The intrafetal course of the persistent right umbilical vein and its association with the gall bladder.

Table 2. Obstetric characteristics and examination findings of the cases diagnosed with persistent right umbilical vein.

\begin{tabular}{lcccl} 
Case & Age & Week of gestation & Fetal sex & Additional fetal finding \\
\hline I & 41 & 18 weeks and 4 days & Female & Echogenic focus in the right ventricle \\
\hline II & 27 & 19 weeks and 1 day & Female & Echogenicity increase in the intestines \\
\hline III & 37 & 23 weeks and 0 day & Male & --- \\
\hline IV & 31 & 24 weeks and 3 days & Male & $\begin{array}{l}12 \times 12 \mathrm{~mm} \text { anechoic cyst on the upper pole of left } \\
\text { kidney (confirmed by the fetal MR imaging) }\end{array}$ \\
\hline V & 27 & 26 weeks and 1 day & Female & Nasal hypoplasia (1.5 percentile) \\
\hline
\end{tabular}

MR: magnetic resonance. 
sists. The blood proceeds from the placenta to the right umbilical vein, then to the right portal vein, to vena cava through ductus venosus and then heart. PRUV proceeds slightly on the parasagittal plane on the right of the midsagittal plane of the fetus. ${ }^{[10]}$

Some studies report PRUV cases usually as isolated anomalies ( $75 \%$ of the cases), and other cord anomalies (single umbilical artery), cardiovascular (ventricular septal defect, tetralogy of Fallot, ARSA), gastrointestinal (omphalocele, esophagus atresia), skeletal (hemivertebra) and urogenital (hydronephrosis, duplicated collecting system, undescended testicle) system problems are among the concomitant anomalies. ${ }^{[2,10,1]}$ In our study, all of the cases found to have PRUV were in the form of IPRUV which is the most common form seen in the literature, and we did not see any concomitant anomaly in any of the cases. We observed minor markers (nasal hypoplasia, echogenic intestine and echogenic cardiac focus) in three of five PRUV cases, anechoic cyst in the upper pole of the left kidney in one case, and no additional finding in one case. We found in the organ system examination that the case with cyst in the renal system was 5 -month infant during the time when we were writing our study and that pediatrics and nephrology clinics recommended 6-month follow-ups for the renal cyst and there was no additional pathology.

Whether there is chromosomal anomaly in PRUV cases or not is the subject of another discussion. Some studies stated that they did not observe chromosomal anomaly while some other studies reported that they found anomaly with a rate of $1.3 \% \cdot{ }^{[12,13]}$ When we reviewed the literature, we found that the fetus of a pregnant woman with Noonan syndrome had also Noonan syndrome as well as PRUV after conducting a chromosomal evaluation. ${ }^{[14]}$ Lide et al. investigated 166,548 pregnant women in their systematic review, and they found PRUV in 212 cases. Of these 212 cases, 3 had chromosomal anomaly, 2 had trisomy 18 and 1 had mosaic Turner syndrome. ${ }^{[13]}$ As highlighted in the studies, the incidence of chromosomal anomaly increases as the concomitant anomalies increase. ${ }^{[2,13]}$ The experience gained throughout the years on the diagnosis of PRUV show that the intrahepatic PRUV with normal ductus venosus connection is a normal anatomic variant without clinical significance in the absence of concomitant anomalies. ${ }^{[3,15]}$ In our cases, we did not find chromosomal anomaly in any of the cases in the evaluation made after labor.
The differential diagnosis of PRUV involves umbilical vein varicose, gall bladder duplication, portal vein anomalies and intrahepatic cysts. ${ }^{[16,17]}$ During the diagnosis, gall bladder has a left-sided view due to the course of PRUV. This should not be confused with the ectopic localization where gall bladder locates in the left lobe lateral segment. It has been shown that this view is associated with the alternative course of the persistent umbilical vein instead of an ectopic gall bladder, and that it is not a localization anomaly of gall bladder ${ }^{[13]}$ As it will prevent diagnostic errors, a careful anatomic evaluation is critical.

\section{Conclusion}

The persistent right umbilical vein is the most common form among fetal venous system anomalies. The fetal abdomen should be evaluated carefully for PRUV diagnosis. The recent studies have highlighted that this anomaly does not increase the rate of chromosomal anomaly or syndromic pattern frequency. However, when PRUV diagnosis is established, cardiovascular, gastrointestinal, skeletal and urogenital systems should be examined carefully in terms of the concomitant anomalies. PRUV should be considered as anatomic variant in cases in which ductus venosus has a normal course.

Conflicts of Interest: No conflicts declared.

\section{References}

1. Canavan TP, Hill LM. Neonatal outcomes in fetuses with a persistent intrahepatic right umbilical vein. J Ultrasound Med 2016;35:2237-41. [PubMed] [CrossRef]

2. Krzyżanowski A, Swatowski D, Gęca T, Kwiatek M, Stupak A, Woźniak S, et al. Prenatal diagnosis of persistent right umbilical vein - Incidence and clinical impact. A prospective study. Aust N Z J Obstet Gynaecol 2019;59:77-81. [PubMed] [CrossRef]

3. Wolman I, Gull I, Fait G, Amster R, Kupferminc MJ, Lessing $\mathrm{JB}$, et al. Persistent right umbilical vein: incidence and significance. Ultrasound Obstet Gynecol 2002;19:562-4. [PubMed] [CrossRef]

4. Leal DB, Maggiolini M, Bianchi A. Prenatal diagnosis and postnatal follow-up of patients with persistent right umbilical vein. Donald School J Ultrasound Obstet Gynecol 2012;6: 104-8. [CrossRef]

5. Achiron R, Hegesh J, Yagel S, Lipitz S, Cohen SB, Rotstein Z. Abnormalities of the fetal central veins and umbilico-portal system: prenatal ultrasonographic diagnosis and proposed classification. Ultrasound Obstet Gynecol 2000;16:539-48. [PubMed] [CrossRef] 
6. Yagel S, Kivilevitch Z, Cohen SM, Valsky DV, Messing B, Shen $\mathrm{O}$, et al. The fetal venous system, Part II: ultrasound evaluation of the fetus with congenital venous system malformation or developing circulatory compromise. Ultrasound Obstet Gynecol 2010;36:93-111. [PubMed] [CrossRef]

7. Ami MB, Perlitz Y, Matilsky M. Prenatal sonographic diagnosis of persistent right umbilical vein with varix. J Clin Ultrasound 1999;27:273-5. [PubMed] [CrossRef]

8. Jeanty P. Persistent right umbilical vein: an ominous prenatal finding? Radiology 1990;177:735-8. [PubMed] [CrossRef]

9. Chaoui R, Kalache KD, Hartung J. Application of threedimensional power Doppler ultrasound in prenatal diagnosis. Ultrasound Obstet Gynecol 2001;17:22-9. [PubMed] [CrossRef]

10. Weichert J, Hartge D, Germer U, Axt-Fliedner R, Gembruch U. Persistent right umbilical vein: a prenatal condition worth mentioning? Ultrasound Obstet Gynecol 2011; 37:543-8. [PubMed] [CrossRef]

11. Adiego-Calvo I, Saviron-Cornudella R, Martinez-Payo C, Rubio-Aranda E, Sancho-Sauco J, Cisneros-Gimeno AI, et al. Are congenital malformations more frequent in fetuses with intrahepatic persistent right umbilical vein? A comparative study. Taiwan J Obstet Gynecol 2016;55:782-5. [CrossRef]
12. Sun L, Wang Y. Demographic and perinatal outcome data of fetuses with SUA/PRUV. J Matern Fetal Neonatal Med 2018; 31:1118-23. [PubMed] [CrossRef]

13. Lide B, Lindsley W, Foster MJ, Hale R, Haeri S. Intrahepatic persistent right umbilical vein and associated outcomes: a systematic review of the literature. J Ultrasound Med 2016;35:15. [PubMed] [CrossRef]

14. Bradley E, Kean L, Twining P, James D. Persistent right umbilical vein in a fetus with Noonan's syndrome: a case report. Ultrasound Obstet Gynecol 2001;17:76-8. [PubMed] [CrossRef]

15. Blazer S, Zimmer EZ, Bronshtein M. Persistent intrahepatic right umbilical vein in the fetus: a benign anatomic variant. Obstet Gynecol 2000;95:433-6. [PubMed] [CrossRef]

16. Kinoshita LL, Callen PW, Filly RA, Hill LM. Sonographic detection of gallbladder duplication: two cases discovered in utero. J Ultrasound Med 2002;21:1417-21. [PubMed] [CrossRef]

17. Mavrides E, Moscoso G, Carvalho JS, Campbell S, Thilaganathan B. The anatomy of the umbilical, portal and hepatic venous systems in the human fetus at 14-19 weeks of gestation. Ultrasound Obstet Gynecol 2001;18:598-604. [PubMed] [CrossRef] 